\title{
Delegation af lovgivningsmagt: Risiko for ringere regulering?
}

\author{
Morten Jarlbæk Pedersen, Geert Laier Christensen \& Jacob Ravn
}

Indledning

Delegation af lovgivningsmagt er et emne, der har fyldt meget i litteraturen både inden for jura, statskundskab og økonomi. Således har både delegationens omfang og natur været genstand for debat i forskellige sammenhænge (se f.eks. de meget forskelligartede tilgange til emnet hos CEPOS 2009; Jakobsen \& Mortensen 2014; Majone 1996). En ofte fremført tese i denne forbindelse er bevægelsen i retningen af en "regulerende stat", dvs. bort fra både en liberal minimalstat og en keynesiansk stat med fokus på omfordeling (Majone 1996, 54-55; 1999). Denne bevægelse betyder, at en stadig større del af samfundsøkonomien reguleres teknisk på baggrund af delegerede beføjelser frem for som resultatet af politisk deliberation. Det bærende argument for udviklingen er, at reguleringen ganske enkelt bliver af højere kvalitet, idet ekspertbåren regulering udgør en 'definitiv forbedring over for hidtidige praksisser' (Majone 1996, 11). Udviklingen fører til to spørgsmål, som søges adresseret i denne artikel: Hvorledes manifesterer bevægelsen mod den regulerende stat sig - hvordan ser delegation ud i Danmark, og hvilket omfang tager den? Og kan det sandsynliggøres, at denne danske variant af den regulerende stat kan levere den kvalitet og effektivitet og dermed legitimitet, som anføres som argumentet for denne udvikling? At svare på dette spørgsmål om delegationens form og modus fordrer et tværdisciplinært udgangspunkt med brug af begrebsapparater fra både statskundskaben og juraen.

Artiklen falder i to dele. Den først del søger at diskutere begreberne legitimitet og delegation i en dansk kontekst. Derfor redegøres kort for de både deskriptive og normative aspekter af begrebet "den regulerende stat", og de gængse argumenter for delegation (De Mesquita \& Stephenson 2007, 605), der eksempelvis fremdrages af Majone (1996) nuanceres og kontekstualiseres. Den danske udgave af den regulerende stat benytter sig nemlig ikke af agenturer som forudsat af Majone, men derimod af delegation direkte til ministre. Dermed opnås ikke den politiske uafhængighed og fokus på kvalitet og effektivitet, som delegationen ellers skal sikre; dette øger betydningen af andre - særligt juridiske - mekanismer til at sikre denne kvalitet og output-legitimitet. Disse mekanismer vil derfor også være 
genstand for diskussion i et særskilt afsnit. Ydermere betyder den særlige danske måde at delegere lovgivningsmagt på, at også mere traditionelle kilder til input-legitimitet kort bør drøftes, hvis vi fyldestgørende skal kunne diskutere begreberne legitimitet og delegation. Konklusionen på disse teoretiske overvejelser er, at både output- og input-legitimiteten af brugen af delegation i Danmark i al fald teoretisk afhænger af, hvor meget delegation anvendes.

I artiklens anden del undersøges derfor brugen delegation i Danmark. Fokus er særligt på erhvervsområdet, da dette som udgangspunkt er den regulerende stats genstandsfelt. I lighed med andre studier (Jakobsen \& Mortensen 2014) konkluderes, at brugen af delegation i almindelighed har været stigende, men dette studium supplerer diskussionen ved at foretage en dybere kvalitativtjuridisk undersøgelse og diskussion af måden, hvorpå vi griber delegation an i Danmark.

Hvad er "den regulerende stat", og hvordan ser den ud i Danmark?

"Reguleringsstaten" er et begreb, der er anvendt til at beskrive den stadig mere teknisk-rationelle tilgang til regulering af samfundsøkonomien. Begrebet søger altså at beskrive en statsform, hvor regulering sker teknisk-rationelt gennem delegation til eksperter og ikke som følge af mere flygtige politiske vinde. Begrebet kan forstås både deskriptivt og normativt, og italieneren Giandomenico Majone, der stod fadder til begrebet, repræsenterer begge (Majone 1994; 1996; 1998). Dette afsnit dvæler ved den første og deskriptive anvendelse af begrebet, idet denne i et ikke ubetydeligt omfang dikterer indholdet og holdbarheden af det normative argument.

Majone beskriver en udvikling med etablering af institutioner, hvortil delegeres lovgivningsmagt på et bestemt område - etableringen af agenturer. Udgangspunkt er således, at delegationen har tre karakteristika: Den er defineret i politisk-økonomisk termer, den har en politisk uafhængig institution som mål, og den er varig. I en dansk sammenhæng har der ikke været tradition for at anvende agenturer med selvstændige reguleringsbeføjelser. Nationalbanken og på enkelte punkter også Konkurrence- og Forbrugerstyrelsen er undtagelserne. Da delegation i Danmark således tager en anden form end forudsat af Majone, må vi kort undersøge denne form; de formelle rammer er jo en forudsætning for det normative argument for øget delegation.

I Danmark antager delegation en ganske særlig juridisk form, nemlig anordningens eller bekendtgørelsens. Denne type delegation adskiller sig fra delegation til et agentur på alle de tre karakteristika nævnt før: For det første sker udstedelse af anordninger og bekendtgørelser diskretionært. Dette betyder, at delegationen er knyttet til et konkret og specifikt regulatorisk tiltag frem for af mere almen karakter. Dermed opstår en diskrepans mellem den danske måde at håndtere 
delegation på og så den måde, der fremdrages af Majone. Hvor den af Majone forudsete delegation er af politisk-økonomisk karakter - dvs. at der delegeres bemyndigelse til at regulere et bestemt politisk-økonomisk område af samfundet - så er delegation i Danmark ofte af mere snæver, juridisk karakter. For det andet sker delegation som oftest ved en bemyndigelse af en minister. Hvor den regulerende stat har politisk uafhængige institutioner som mål for delegationen, foretages delegation i Danmark fra en politisk instans (Folketinget) til en anden politisk instans (en minister) frem for til en instans af teknisk-regulativ karakter. For det tredje sker delegationen i forbindelse med den almindelige lovudstedelse; der er ikke tale om en generel og endegyldig delegation, og dermed bliver de danske ministres myndighed til at udstede bekendtgørelser direkte afhængige af skiftende flertal i Folketinget - modsat f.eks. Nationalbankens myndighed over den danske pengepolitik.

Det normative grundlag for den regulerende stat er kort og godt et ønske om samfundsøkonomisk efficiens, og Majones argumenter for delegation kan ses som et forsøg på at vise, hvorledes dette ønske i højere grad kan indfries. Samtidig understreger Majone, at da delegation sker for at gøre reguleringen mere effektiv, bør netop reguleringens effektivitet også være den legitimitetsstandard, vi opsætter, når delegationen som sådan skal vurderes (Majone 1998). Andre og mere klassiske legitimitetskriterier - eksempelvis repræsentation - kan sagtens gøre sig gældende, men udgangspunktet er output-legitimiteten, om man vil (Beetham \& Lord 1998; Scharpf 2009).

Spørgsmålet er nu, om dette normative argument for øget delegation også er holdbart i en dansk sammenhæng, hvor delegationen - som vist - antager en ganske anden modus end forudsat af Majone? Hvordan skal vi anskue gyldigheden af Majones argument om, at delegation er ønskværdigt, da det medfører en mere afpolitiseret og teknisk tilgang til reguleringen, når delegationen sker på en helt anden måde end til de agenturer, hans argument støtter? Eller sagt mere direkte: Kan vi forvente, at delegation "på dansk" vil kunne opnå samme output-legitimitet som delegation til agenturer?

Med udgangspunkt i Majones argument om kvalitet og effektivitet som legitimitetskilde, må vi derfor undersøge, hvordan netop kvaliteten og effektiviteten af reguleringen sikres, når den nu ikke sikres ved at leve op til de tre forudsætninger for delegation, som Majone opstiller. Dette munder ud i en kort diskussion af begrebet regulatorisk kvalitet efterfulgt af en undersøgelse af de processuelle tiltag, der skal sikre denne kvalitet som forudsætning for effektiv virkning og dermed i sidste ende output-legitimiteten. Dernæst må det bemærkes, at forskellen mellem Majones udgangspunkt og de danske realiteter nødvendiggør, at spørgsmålet om input kort må berøres. Konklusionen på baggrund af disse to nedenstående afsnit er, at omfanget af delegationen i Danmark er altafgørende for en 
vurdering af delegation som begreb. Dette fordrer naturligvis en viden om netop omfanget af delegationen i Danmark, hvilket efterfølgende søges klarlagt.

\section{Begrebet kvalitet - forudsætningen for Majones normative argument}

Majones $(1996 ; 1998 ; 1999)$ tese er, at delegation af reguleringsbeføjelser vil sikre, at reguleringen er mere effektiv og efficient, hvilket i sig selv forlener den med legitimitet. Det kan dog være vanskeligt, grænsende til det umulige, at afgøre en retsakts samfundsøkonomiske efficiens, idet denne afhænger af så utrolig mange faktorer. Én faktor, der dog med en vis vægt kan siges at have tværgående relevans, er den regulatoriske kvalitet af de regler, der gælder. Et underliggende aspekt af Majones argument er således, at den regulerende stat medfører en højere kvalitet i reguleringen ikke mindst på grund af uafhængigheden af de agenturer, der er genstand for delegeret lovgivningsmagt. Denne tese er senere også taget op af f.eks. Radaelli \& de Franscesco $(2007,28)$, der benævner kvalitet det "kognitive anker" i diskussionerne om bedre regulering.

Begrebet "kvalitet" er imidlertid sjældent undersøgt nærmere i den politologiske litteratur, der i stedet har fokuseret på metaregulering. Denne forskning er bl.a. præget af Radaellis arbejder, og disse studier har blandt andet kastet lys på begrebet metaregulering (Hansen \& Pedersen 2006; Radaelli \& Meuwese 2009), på konsekvensvurderinger af kommende regulering og kontekstafhængigheden af metaregulatoriske tiltags virkning (Radaelli 2004, 2005; Stern \& Holder 1999; Wiener 2006). Perspektiverne varierer selvsagt, men det ses, at kvalitet sjældent har været behandlet $\mathrm{i}$ egen ret (Pedersen 2015). I stedet er regulatorisk kvalitet et begreb, der enten bruges som variabel i mere økonomisk orienterede studier af sammenhængen mellem regulatorisk kvalitet og økonomisk formåen og udvikling (Djankov, McLiesh \& Ramalho 2006; Haidar 2012; Huynh \& Jacho-Chávez 2009; Jalilian, Kirkpatrick \& Parker 2007; Rodrik 2005; Stern \& Cubbin 2005), eller et begreb, som defineres i juridiske termer (se f.eks. Bormann, Bülow, \& Østrup 2002; Müller \& Uhlmann, 2013; Painter, 2009).

Det juridiske fokus har mindst to væsentlige styrker: Den ene er, at det tillader os at definere regulatorisk kvalitet som en egenskab ved et konkret stykke lovgivning; dermed fås et veldefineret analyseobjekt. Den anden styrke er, at det tillader os at adskille begrebet regulatorisk kvalitet fra mere normative vurderinger af en retsakts formål (Fliedner 2001). Denne juridiske tilgang er naturligvis inspireret af en bestemt juridisk skole, nemlig en retsdogmatisk (Wegener 2000, 51-60) eller "lawas-rules"-tilgang (velbeskrevet i Van Hoecke \& Warrington 1998, der dog argumenterer for en 
bredere tilgang) kombineret med inspiration fra retspositivisme (Kelsen 1928). Denne snævre, juridiske tilgang er dog hæmmet af, at den alene ser på det juridiske landskab. Hvis fokus er på potentialet for reglernes effektive virkning, må den juridiske tilgang kombineres med en erkendelse af det ikke-juridiske landskabs betydning: Giver reglerne faktisk mening i den virkelighed, de skal virke i - er de reelt applicérbare? At den regulatoriske kvalitet således forstået har betydning, er ikke alene et spekulativt argument, men har empirisk resonans. Reregulering - og ikke blot afskaffelse af regler $\mathrm{i}$ form af deregulering - har været det centrale omdrejningspunkt for megen politisk og administrativ indsats under overskriften "bedre regulering" (Pedersen \& Pasquali 2009, 70), ligesom også nyere tiltag som f.eks. Virksomhedsforum bl.a. arbejder ud fra denne bagvedliggende forståelse af reglernes kvalitet som udgangspunkt for deres effektive virkning og dermed for deres betydning for den samfundsøkonomiske efficiens af reguleringen som sådan.

Denne regulatoriske kvalitet - f.eks. om reglerne er modstridende, eller om de indeholder juridiske begreber, der ikke er veldefinerede, og om de er reelt applicérbare - kan man god ret argumentere for, har relevans i alle regulatoriske sammenhænge, herunder ikke mindst om reguleringen vil være i stand til at opnå sit mål (Bălan 2011; Bormann et al. 2002, 13-16; Kaeding 2008). Bemærk dog venligst, at der her tales om relevans - ikke kausalitet. Som et af meget få aspekter af sikringen af den samfundsøkonomiske efficiens af regulering har kvalitet med andre ord bred betydning for reglernes effektive virkning og dermed for deres output-legitimitet. Samtidig står det klart, at netop den regulatoriske kvalitet i den regulerende stat søges sikret ved, at reguleringen foretages af et afpolitiseret agentur. I Danmark bruges ikke slige agenturer, så derfor må vi undersøge virkningen af eventuelle andre metoder til at sikre denne regulatoriske kvalitet.

\section{Hvordan sikres den regulatoriske kvalitet i Danmark?}

Metoderne til at sikre regulatoriske kvalitet er afhængig af den juridiske form, og særligt love og bekendtgørelser er her relevante at dissekere yderligere. For det første er de meget ens forstået, da der i begge tilfælde er tale om autoritativ udstedelse af regler - ikke fortolkninger af eksisterende regler som ved domsafsigelser eller vejledninger (Germer 2007, 14, 111-112). Desuden retter de sig begge mod borgere og virksomheder, hvor f.eks. cirkulærer retter sig mod interne forhold den offentlige sektor alene (Germer 2007, 112; Sørensen 1999, 42).

Helt grundlæggende vedtages love, mens bekendtgørelser udstedes. Sprogligt kan forskellen virke subtil, men reelt er den ganske stor. Før en lov kan vedtages, fordrer det nemlig ikke blot et simpelt flertal blandt Folketingets medlemmerne; der er også en række proceskrav, hvis formål bl.a. 
er at sikre netop den regulatoriske kvalitet. I Danmark findes fem sådanne kontrolmekanismer, der skal sikre en grundig behandling af lovforslag:

1) Kravet om tre behandlinger i Folketinget, der følger af Grundlovens $\S 41$.

2) En række krav til bestemte tidsfrister f.eks. mellem de tre folketingsbehandlinger. Disse krav følger af både Grundloven og Folketingets forretningsorden (Danmarks Riges Grundlov 1953; Folketinget 2013, §§ 10-15).

3) Brugen af (stående) udvalg til at bearbejde forslag mellem de tre folketingsbehandlinger; brugen af disse følger af Folketingets forretningsorden (Folketinget 2013, §§ 7-9).

4) Brugen af høringer til at oplyse det lovforberedende arbejde og Folketingets udvalgsarbejde som beskrevet i Justitsministeriets vejledning i lovkvalitet (Justitsministeriet 2005, 55-58).

5) Kravet om konsekvensvurderinger som fastsat $i$ et statsministerielt cirkulære (Statsministeriet 1998) og yderligere beskrevet i Finansministeriets vejledning til udarbejdelse af konsekvensvurderinger (Finansministeriet 2005).

Disse fem kontrolmekanismer og ikke mindst samspillet mellem dem skal medvirke til at sikre den regulatoriske kvalitet.

Som udgangspunkt er delegeret lovgivning i Danmark, anordninger og bekendtgørelser, ikke underlagt nogen kontrolmekanismer, idet "Forslag til samme ikke i Rigsdagen undergives den for Lovforslag foreskrevne Behandlingsmaade" (Matzen 1900, 23). Det kan dog indvendes, at visse af de fem kontrolmekanismer er relevante alligevel. For det første fordi bekendtgørelser er underlagt formelle krav om kontrasignatur og ministeransvar (Germer 2007, 118). Dette har dog ingen betydning for indholdet og dermed ej heller for dens regulatoriske kvalitet. For det andet følger det af det almindelige legalitetsprincip (Germer 2007, 99-100), at udstedelse af en bekendtgørelse kræver lovhjemmel, og den bagvedliggende bemyndigelses- eller fuldmagtslov vil jo have gennemgået ovenstående kontroller før vedtagelse. At fuldmagtsloven er underlagt disse kontrolmekanismer til at sikre den nødvendige grundighed i lovgivningsprocessen, betyder dog ikke, at de delegerede retsakter er det. Medmindre det ekspliciteres ganske nøje i selve forslaget, hvad de delegerede retsakter vil indeholde, kan eksempelvis konsekvensvurderingerne ikke tage højde for bekendtgørelser, der udstedes med hjemmel i den vedtagne lov. Selvom der til brugen af delegation generelt stilles krav om mere omfattende lovbemærkninger (Bormann et al. 2002, 36), fremstår et krav om konsekvensvurderinger af afledte retsakter sammen med bemyndigelsesloven umuligt at 
imødekomme. Dette understreges også af, at visse love, såkaldte samlelove, vedrører meget forskellige emner og områder (Bormann et al. 2002, 29-30; Pedersen, Ravn, \& Christensen 2014), hvorfor mange konsekvensvurderinger i forvejen er spage. Skulle konsekvensvurderinger tillige indregne konsekvenserne af endnu ikke formulerede regelsæt i kommende bekendtgørelser, ville dette udvande konsekvensvurderingerne yderligere. Desuden ønsker man ikke at imødekomme kravet om konsekvensvurderinger af f.eks. bekendtgørelser allerede i fuldmagtsloven. Der er nemlig tale om to separate retsakter, der pr. definition skal behandles separat, selvom de står i et indbyrdes afhængighedsforhold og tjener samme politiske formål; det er i al fald opfattelsen visse steder i centraladministrationen (Erhvervs- og Vækstministeret 2013).

Ovenstående er dog ikke ensbetydende med, at bekendtgørelser og anordninger ikke konsekvensvurderes. Bekendtgørelser fra erhvervsrettede ministerier skal nemlig underkastes en konsekvensvurdering i Erhvervsstyrelsen (Finansministeriet 2005, 9). Denne slags konsekvensvurdering er dog ikke et juridisk krav, og den har næppe så vidtrækkende implikationer som konsekvensvurderinger af lovforslag, idet bekendtgørelser ikke er underlagt de andre proceskrav; en positiv samspilseffekt mellem de forskellige proceskrav opstår således i langt mindre grad. Særlig tre af de andre krav og deres forhold til konsekvensvurderingerne og til hinanden er relevante: Tidsfrister, der sikrer, at konsekvensvurderinger finder sted så tidligt, at de kan nå at påvirke beslutningsprocessen; krav om høring, som kan tilføje oversete aspekter til konsekvensvurderingen; og antallet af vetopunkter, som øger relevansen af en konsekvensvurdering, da ikke kun den udstedende myndighed (som jo har taget stilling) skal overbevises om regulering i en bestemt retning. Disse tre krav findes ikke i samme omfang for bekendtgørelser, hvorfor de potentielle følger af en misvisende konsekvensvurdering af en bekendtgørelse er væsentligt mindre end for lovforslag.

Af ovenstående kan konkluderes, at delegation i Danmark ikke nødvendigvis sikrer en tekniskrationel tilgang til reguleringen. Dette skyldes for det første, at delegationen sker til en politisk instans - en minister - og ikke til en uafhængig instans friholdt fra almindelige, politiske incitamenter; og det skyldes for det andet, at de proceskrav, der gælder i forbindelse med vedtagelse af lovforslag, og som netop skal korrigere politiske vilkårligheder og sikre den regulatoriske kvalitet, ikke i samme omfang som ved almindelige love finder anvendelse. Det betyder ikke, at delegation som sådan er utilrådelig; det betyder blot, at det er uhyre vigtigt, hvilke og hvor mange beføjelser det overlades til ministeren at udøve. Dermed bliver især omfanget af delegationen af afgørende betydning. Jo oftere og jo bredere, der anvendes delegation, des større bliver risikoen for, at ovenstående problemer vil 
medføre regulering af lavere kvalitet. Hvis delegationen i Danmark er stigende, står vi med andre med stigende risiko for, at output-legitimiteten lider skade - til trods for, at denne output-legitimitet ofte bruges som argumentet for selvsamme delegation.

Input-legitimitetens relevans i den regulerende stat i dens danske udgave

Opsummerende kan det altså slås fast, at delegation i Danmark medfører en højere grad af risiko for politiseret regulering. Dermed sættes Majones grundlæggende argument, om at den teknisk-rationelle tilgang til regulering nødvendiggør et altovervejende teknisk-rationelt legitimitetskriterium, ud af kraft. Af dette følger, at vi må kigge nøjere på delegationens demokratisk-legitime grundlag, dens input-legitimitet. Ud fra gængse forestillinger om parlamentarisk kontrol med regeringen (Olsen 1978) er der meget, der taler til fordel for den danske måde at håndtere delegation på sammenlignet med den varige delegation af lovgivningsmagt til ikke-valgte organisationer: Der opretholdes parlamentariske kontrol med reguleringens indhold - om ikke andet så indirekte. Dette understøttes også af, at delegationen sker diskretionært; ministrene får kun lov til at udstede de regler, som Folketinget bemyndiger ministeren til.

Imidlertid afhænger denne positive vurdering af det danske system i høj grad af omfanget af delegationen på mindst to måder. For det første er der det blotte antal af delegationsbeføjelser; dette må antages at have et naturligt loft, da man ellers på det nærmeste ville bemyndige regeringen til at stå over Folketinget. For det andet er der delegationens materielle indhold. Hvis ministeren ikke blot kan udstede regulerende regler, men tillige diktere overordnede retsprincipper, har Folketinget reelt sat sig selv uden for indflydelse. Der er altså grænser for delegation (Germer 2007, 100-102; Sørensen 1999, 41-42). Samtidig er det værd at bemærke, at delegationen jo sker til et politisk organ. Dermed må det som nævnt tidligere forventes, at reguleringen - selvom delegationen er foretaget ud fra et vurdering af et emnes tekniske karakter - kan antage politiske dimensioner og præges af de politiske incitamenter, som ministre er underlagt - herunder f.eks. ønske om genvalg og understøttelse af egne vælgergrupperinger. Dette understreger igen blot vigtigheden af omfanget: eventuelle politiske prioritetsforskydninger må antages at blive flere, jo større muligheden herfor bliver.

Sammenfattende kan det slås fast, at både argumentet om, at delegation er legitim, idet den bygger på en teknisk-rationel logik og dermed sikrer en højere kvalitet, og argumentet om, at delegationen er legitim, idet den sker parlamentarisk og diskretionært, afhænger af delegationens formelle og 
materielle omfang: jo mere delegationen bruges, des større bliver risiciene. I det følgende er derfor foretaget en undersøgelser af delegationsomfanget i Danmark, hvor vi går i dybden med udviklingen inden for det erhvervspolitiske område, idet den teknisk-rationelle tilgang til delegation her må forventes at være særlig relevant.

\section{Metodiske overvejelser}

Det foreliggende studium bygger på materiale fra retsinformation.dk og lovtidende.dk, der samler "alle love og regler (...), der udstedes af ministerierne og de centrale, statslige myndigheder, og (...) Folketingets dokumenter" (Civilstyrelsen udateret). Studiet bygger videre på andre studier, hvor særligt Jakobsen \& Mortensen (2014) skal fremhæves. Formålet her er nemlig at supplere tidligere undersøgelser - som deres - af delegationens omfang. Sådanne undersøgelser omfatter typisk nye bekendtgørelser (Christensen 1991, 247; Jakobsen \& Mortensen 2014, 39) og ser bort fra ændringer i eksisterende bekendtgørelser. Dermed fokuseres på regelproduktion frem for sanering. Derved overses, at f.eks. ændringsbekendtgørelser kan medføre nye regler, hvorfor en slig opgørelse sandsynligvis undervurderer omfanget af delegation forstået som delegeret regelfastsættelse. Ikke desto mindre kan disse undersøgelser bekræftende besvare det bagvedliggende spørgsmål: Antallet af nye bekendtgørelser er stigende relativt til antallet af nye love (Jakobsen \& Mortensen 2014, 46).

Jakobsen \& Mortensens undersøgelse fokuserer på fire love med samlet begrænset erhvervsregulatorisk relevans. Det her foreliggende studium undersøger derimod specifikt erhvervsregulering, da denne er omdrejningspunktet for den regulerende stat. Målet har således været at undersøge udviklingen i omfanget af delegationen i en række af den mest centrale love til regulering af erhvervslivet. For at identificere disse love blev en række juridiske eksperter i erhvervsorganisationen Dansk Erhverv konsulteret. I praksis foregik det således, at vi kontaktede et antal erhvervsjurister i pågældende organisation og bad dem liste de love, der er vigtigst inden for deres respektive felter. De 8 erhvervsjurister, der svarede, pegede på 15 love, som må forventes at være blandt de mest relevante kilder til regulering af erhvervslivet $\mathrm{i}$ almindelighed. En del blev nævnt ad flere omgange af de juridiske eksperter. En enkelt lov, straffeloven, er blevet udeladt her, da denne lovs fokus ikke er regulering af erhvervslivet, men håndtering af (strafferetlige) konsekvenser af brud på denne og anden regulering. De tilbageværende 14 love, som vi altså ikke har kvalificeret yderligere, er blevet analyseret $\mathrm{i}$ tre trin.

Første trin var juridisk identifikation af lovene, som de så ud i 1990, 2000, 2010 og 2013. Målet hermed var at opbygge en oversigt over retsudviklingen pr. tiende år, således at udviklingen $i$ 
delegation kunne undersøges i et juridisk datasæt bestående af 4 gange 14 love. Udgangspunktet var lovbekendtgørelser eller officielle, juridiske datasammenskrivninger for de pågældende år, da lovbekendtgørelser og datasammenskrivninger "opsummerer" den gældende lovgivning. Det var imidlertid ikke muligt at identificere lovbekendtgørelser eller datasammenskrivninger for alle lovene for alle årene, hvorfor vi i visse tilfælde har konstrueret vor egen datasammenskrivning. Dette er sket på grundlag af den senest mulige lovbekendtgørelse eller datasammenskrivning før året med tillæg af efterfølgende ændringer frem til og med analyseåret. På denne baggrund er der nået fuldt overblik over gældende lovgivning i 1990, 2000, 2010 og 2013. Halvdelen af de 14 undersøgte love fandtes i alle fire udgaver; resten i tre eller færre. Der kan være tre årsager til, at en lov ikke kunne findes i alle fire udgaver: Loven kunne være forblevet uændret i en hel tiårsperiode efter 1990 (det gælder f.eks. handelsagentloven fra 1990); loven fandtes ikke et givent år (det gælder f.eks. selskabsloven, der er en sammenskrivning af aktieselskabsloven og anpartsselskabsloven, og det gælder f.eks. vikarloven, der implementerer EU-regulering), eller en kombination af disse to ting.

Det andet trin var en identifikation af bestemmelser, der indeholder delegationsbeføjelser. De op til 4 gange 14 love blev derfor nøje undersøgt med henblik på at identificere samtlige delegationsbestemmelser. For at sikre undersøgelsen validitet (at vi rent faktisk oplister omfanget af delegation og intet andet (Adcock \& Collier 2001, 530) og reliabilitet (muligheden for, at undersøgelsen kan repliceres)) var metodikken at forlade sig så lidt på fortolkning som muligt. Optællingen indeholder således alene bestemmelser, hvori delegationen er fuldkommen entydig. Dette er eksempelvis tilfældet, når der står "ministeren bemyndiges til at fastsætte regler om...". Kodningen skete manuelt, da vi ikke - som er en forudsætning for automatiseret optælling - kan forudsige samtlige formuleringer, der godtgør delegation. Ydermere er optællingen sket alene på paragraf- og paragrafstykkeniveau. Denne tilgang er valgt særligt med henblik på reliabiliteten af undersøgelsen, selvom vi med denne metode risikerer at undervurdere delegationsomfanget. Denne risiko for skævhed i opgørelsen forårsages af, at der i flere paragraf(stykker) er oplistet flere delegationsbeføjelser f.eks. ved at opliste en række punkter, som ministeren nærmere kan definere. Det er eksempelvis tilfældet i markedsføringslovens $\S 13$, stk. 8. I vores opgørelse er en sådan delegation kun talt én gang, selvom der i streng juridisk forstand muligvis er tale om flere delegationsbeføjelser. En lignende tilgang med fokus på simpel optælling er anvendt hos Jakobsen \& Mortensen (2014), selvom opmærksomheden på denne metodes konservative islæt synes at være til at overse. Optællingen ledte til en oversigt over omfanget af delegation i hver enkelt lov i hver af de 
fire udgaver af denne lov. Disse fire oversigter kunne derefter sammenlignes for at afgøre udviklingen i omfanget af delegation i den givne lov.

Det tredje trin var en kvalitativ kontrol af hver enkelt identificeret delegationsbeføjelse. Formålet var her at undersøge, om delegationen substantielt ændrede sig, idet trin 2 af undersøgelsen reelt har tre indbyggede potentielle fejlkilder: For det første kan udviklingen indeholde sammenskrivninger af delegationsbeføjelser til én samlet og bredere beføjelse. Og for det andet kan man støde på eksplicitering af hidtil bredere beføjelse (den omvendte situation af den første fejlkilde). Disse to fejlkilder vil blandt andet betyde, at omfanget af delegation reelt set er konstant fra år til år, selvom analysen på trin 2 vil afsløre en bevægelse i nedad- hhv. opadgående retning. En grundigere juridisk undersøgelse af delegationens indhold kan afsløre, om dette er tilfældet og sikre en korrektion. For det tredje kan enkeltbestemmelser (et enkelt paragrafstykke) indeholde mere end én delegationsbeføjelse, jf. eksemplet med markedsføringslovens $\S 13$, stk. 8 ovenfor. Hvis denne fejlkilde er til stede, vil det betyde, at undersøgelsen undervurderer det reelle delegationsomfang. Markedsføringsloven er ikke det eneste eksempel herpå; f.eks. giver $\S 55$, stk. 3 i selskabsloven Erhvervsstyrelsen mulighed for "at fastsætte nærmere regler om besiddelse og om meddelelse om besiddelse af kapitalandele" og "endvidere [at] fastsætte regler, som fraviger stk. 1, for så vidt angår aktier i aktieselskaber, som har aktier optaget til handel på et reguleret marked eller en multilateral handelsfacilitet...”. Som følge af undersøgelsens metodik vil denne delegation kun tælle med én gang. Dette konservative estimat er dog prisen for den metodiske styrke, for så vidt angår validitet og reliabilitet, som er beskrevet under trin 2. Opsummerende kan siges, at det tredje trin af undersøgelsen havde til formål at afsløre en "falsk" stigning eller fald i omfanget delegation, f.eks. ved at en delegationsbeføjelse blev splittet op i to eller samlet i én paragraf. Denne juridiske undersøgelse af de enkelte paragrafstykker kvalificerede undersøgelsen på det andet trin med henblik på at øge validiteten; dette kvalificerende trin synes ej heller at have været genstand for tidligere undersøgelsers interesse.

\section{Brugen af delegation i dansk erhvervsregulering}

Undersøgelser af delegation på alle lovområder afslører en temmelig entydig tendens, idet antallet af udstedte bekendtgørelser er stigende set $\mathrm{i}$ forhold til antallet og omfanget af nye love; dog spores en faldende tendens (Jakobsen \& Mortensen 2014, 46-50). Dette billede kan tolkes på to måder: For det første kan det ses som udtryk for større brug af "samlelove", dvs. love, der samler mange love i ét forslag. Hvis brugen af sådanne lovforslag er stigende, vil det opgjorte antal lovforslag være lavere 
end det "reelle" antal lovforslag. Muligheden af denne effekt synes ikke at have fanget interesse i andre opgørelser. Der findes undersøgelser, der tyder på, at en sådan effekt gør sig gældende (Pedersen et al. 2014), om end den næppe er afgørende for konklusionerne her. For det andet kan det tolkes som et billede af, at delegationsgraden $\mathrm{i}$ almindelighed har været stigende, men muligvis bevæger sig mod et "mæthedspunkt" (Jakobsen \& Mortensen 2014, 50). Sandsynligvis gør begge dele sig gældende, om end det forekommer mest sandsynligt, at delegationsgraden er steget mere end brugen af samlelove.

Sådanne oversigter siger dog ikke noget om delegationsgraden specifikt i dansk erhvervsregulering, hvorfor vi må ty til den mere kvalitative undersøgelse. Denne analyse bestod som tidligere nævnt af tre trin. Det første trin var en identifikation af de 14 udvalgte love, sådan som de så ud i hhv. 1990, 2000, 2010 og 2013. Nogle af lovene skulle som beskrevet ovenfor kun identificeres én gang (f.eks. CMR-loven og handelsagentloven), mens andre fordrede større indsats at kortlægge. F.eks. er datagrundlaget for 2000-udgaven af forbrugeraftaleloven en datasammenskrivning fra 1993 (DSK nr. 11031 af 22. juni 1993), hvortil er lagt de ændringer af loven, der fulgte i hhv. 1994 (lov nr. 1098 af 21. december 1994) og 2000 (lov nr. 442 af 31. maj 2000). En oversigt over de analyserede love ses i tabel 1. Som det ses, har det været muligt at identificere halvdelen af de udvalgte kilder til erhvervsregulering i både en 1990-, 2000-, 2010- og en 2013-udgave (bemærk, at 1990-udgaven af søloven tillige inkluderer lov om skibsregistrering (lovbekendtgørelse nr. 588 af 29. september 1988), der senere blev skrevet ind i selve søloven).

Det næste trin i analysen var en gennemgang af disse love, lovbekendtgørelser og datasammenskrivninger for at identificere bestemmelser indeholdende delegation. To parallelle tendenser og en residualgruppe manifesterer sig: I den første gruppe af love ændrer omfanget af delegation sig ikke nævneværdigt. Det gælder aftaleloven, erstatningsansvarsloven og købeloven. Det er meget karakteristisk for lovene i denne gruppe, at delegationsomfanget ikke blot bevarer status quo, men også, at det i udgangspunktet er meget lavt.

Dernæst finder vi en større gruppe af love - det er faktisk halvdelen af de 14 - hvori delegation bruges i stadig stigende omfang gennem hele perioden. Dette gælder godskørselsloven, jernbaneloven, konkurrenceloven, luftfartsloven, markedsføringsloven, selskabsloven og søloven. I nogle af disse love er stigningen i antallet af delegationsbeføjelser mindre (f.eks. i godskørselsloven), mens stigningen $i$ andre er ganske omfattende 


\begin{tabular}{|c|c|c|c|c|}
\hline Populært navn & 1990 & 2000 & 2010 & 2013 \\
\hline Aftaleloven & $\mathrm{X}$ & $\mathrm{X}$ & & $\mathrm{X}$ \\
\hline CMR-loven & $\mathrm{X}$ & & & \\
\hline Erstatningsansvarsloven & $\mathrm{X}$ & $\mathrm{X}$ & $\mathrm{X}$ & \\
\hline Forbrugeraftaleloven & $\mathrm{X}$ & $\mathrm{X}$ & $\mathrm{X}$ & $\mathrm{X}$ \\
\hline Godskørselsloven & $\mathrm{X}$ & $\mathrm{X}$ & $\mathrm{X}$ & $\mathrm{X}$ \\
\hline Handelsagentloven & $\mathrm{X}$ & & & \\
\hline Jernbaneloven & & $\mathrm{X}$ & $\mathrm{X}$ & $\mathrm{X}$ \\
\hline Konkurrenceloven & $\mathrm{X}$ & $\mathrm{X}$ & $\mathrm{X}$ & $\mathrm{X}$ \\
\hline Købeloven & $\mathrm{X}$ & $\mathrm{X}$ & $\mathrm{X}$ & $\mathrm{X}$ \\
\hline Luftfartsloven & $\mathrm{X}$ & $\mathrm{X}$ & $\mathrm{X}$ & $\mathrm{X}$ \\
\hline Markedsføringsloven & $\mathrm{X}$ & $\mathrm{X}$ & $\mathrm{X}$ & $\mathrm{X}$ \\
\hline Selskabsloven & & & $\mathrm{X}$ & $\mathrm{X}$ \\
\hline Søloven & $\mathrm{X}$ & $\mathrm{X}$ & $\mathrm{X}$ & $\mathrm{X}$ \\
\hline Vikarloven & & & & $\mathrm{X}$ \\
\hline
\end{tabular}

Slutteligt kan man pege på en residualgruppe bestående af en række love, hvori det ikke giver mening at tale om en udvikling, idet de kun findes i én udgave i datasættet. Til denne residualgruppe hører desuden forbrugeraftaleloven, hvori delegation øjensynligt benyttes $i$ et faldende omfang. De her beskrevne resultater er opsummeret i tabel 2.

Denne analyse mangler dog den sidste kvalifikation, inden en egentlig konklusion om brugen af delegation i dansk erhvervslovgivning kan drages. Denne kvalificerende undersøgelse skulle afdække, hvorvidt optællingen dækkede over "falske" stigninger eller fald i brugen af delegation. Det viste sig, at alene én situation affødte et behov for kommentarer: Forbrugeraftaleloven. Som det fremgår af tabel 2, indeholdt denne lov i 1990 to bestemmelser med delegationsbeføjelser. Dette var bestemmelser om, at "Justitsministeren kan fastsætte bestemmelser om oplysningens form og indhold”. Dette omhandlede en række oplysningsforpligtelser på særlige områder (f.eks. fjernsalg). 


\begin{tabular}{|l|l|l|l|l|}
\hline \multicolumn{2}{|l}{ Tabel 2. Antal bestemmelser med delegation } \\
\hline Populært navn & 1990 & 2000 & 2010 & 2013 \\
\hline Aftaleloven & 0 & 0 & - & 0 \\
\hline CMR-loven & 1 & - & - & - \\
\hline Erstatningsansvarsloven & 1 & 1 & 1 & - \\
\hline Forbrugeraftaleloven & 2 & 4 & 1 & 0 \\
\hline Godskørselsloven & 12 & 14 & 16 & 17 \\
\hline Handelsagentloven & 1 & - & - & - \\
\hline Jernbaneloven & - & 28 & 66 & 70 \\
\hline Konkurrenceloven & 5 & 16 & 21 & 24 \\
\hline Købeloven & 0 & 0 & 0 & 0 \\
\hline Luftfartsloven & 67 & 77 & 85 & 85 \\
\hline Markedsføringsloven & 7 & 9 & 14 & 19 \\
\hline Selskabsloven & - & - & 26 & 37 \\
\hline Søloven & 18 & - & 41 & 50 \\
\hline Vikarloven & & - & - & 0 \\
\hline
\end{tabular}

Disse oplysningsforpligtelser (og den medfølgende delegation til at fastsætte oplysningsforpligtelserne) valgte man senere hen at udpensle, således at der i 2000-udgaven af forbrugeraftaleloven var fire bestemmelser med delegation - selvom det reelle omfang af delegationen var den samme. Senere hen - i 2010 - valgte man at samle disse fire bestemmelser i én bestemmelse: "Justitsministeren kan fastsætte nærmere regler om indholdet af og formen for de oplysningsforpligtelser, der følger af $\S \S 10-15$. Justitsministeren kan endvidere fastsætte regler om yderligere oplysninger, som den erhvervsdrivende skal give.” Det faktiske omfang af delegationen var dog uændret. Først i 2013-udgaven ses en reel ændring, idet delegationsbemyndigelsen gled ud til fordel for en eksplicitering af informationsforpligtelserne. Selvom dette modificerer lovens historik, så ændrer det dog ikke på det samlede billede af en lov med faldende grad af delegation som den eneste af de 14 analyserede love i øvrigt.

\section{Konklusion}

Denne artikel har sat sig for at gøre to ting: For de første at diskutere de teoretiske begrundelser for brugen af delegation af lovgivningsmagt. Dette blev gjort ved at undersøge begrebet"den regulerende stat" sammenholdt med rammerne for delegation i en dansk kontekst. Den regulerende stat i Danmark manifesterer sig ganske anderledes end forudsat af f.eks. Majone og i litteraturen om den regulerende 
stat, og det betyder, at der må stilles ganske andre krav til den normative vurdering af udviklingen af den regulerende stat i Danmark. Denne ministerielle delegationsform, vi har valgt her til lands, betyder nemlig, at hverken kriteriet om, at delegationen skal være defineret i politisk-økonomisk termer, have en selvstændig og uafhængig institution som mål eller være varig, imødekommes. Dette gælder også for ordinær (lov)regulering, der til gengæld er underlagt en række mekanismer til sikring af den regulatoriske kvalitet; disse mekanismer gør sig imidlertid ikke gældende i samme omfang for delegerede retsakter. Konklusionen er, at både det formelle og materielle omfang af delegationen må være afgørende for metodens almindelige legitimitet, idet risiciene for politiseret regulering af lavere kvalitet ceteris paribus vil være højere, når reguleringen i højere grad sker gennem delegation. En lignende konklusion - at delegationsomfanget har betydning for den normative vurdering - kommer man også til, når der anlægges mere traditionelle parlamentariske legitimitetskriterier.

For det andet og i forlængelse af ovenstående undersøgtes delegationens omfang. Fra tidligere studier ved vi, at brugen af bekendtgørelser i almindelighed er stigende, men denne undersøgelse supplerede og kvalificerede disse opgørelser. Dette skete ved at se nærmere på erhvervsområdet og ved at foretage en mere dybdegående, juridisk analyse af brugen af delegation over tid i de 14 mest centrale erhvervslove. Konklusionen er, at delegationsgraden er stigende både kvantitativt og kvalitativt.

Det samlede billede er således, at hvis delegation i Danmark skal anskues som en legitim kilde til regulering, skal denne reguleringsform bruges med omtanke, da man hverken delegerer reguleringsbeføjelser til uafhængige tekniske instanser eller har installeret kvalitetssikrende mekanismer på samme måde som med almindelige love. Alternativt opstår både problemer med balancen mellem Folketinget og regeringen og risiko for lavere regulatorisk kvalitet. Om kvaliteten rent faktisk er faldende, er et empirisk spørgsmål, som denne artikel ikke har afdækket, men som - i forlængelse af det her fremførte argument om øget risiko for ringere regulering - passende kunne tages op i forskningen fremover.

NØGLEORD: Regulering, kvalitet, erhvervspolitik, delegation 


\section{Litteratur}

Adcock, R \& Collier, D 2001, 'Measurement validity: A shared standard for qualitative and quantitative research', American Political Science Review, vol. 95, no. 3, pp. 529-546.

Bălan, E 2011, 'The Quality of Regulation', Acta Universitatis Danubius Juridica, vol. 7, no. 3, pp. $67-71$.

Beetham, D \& Lord, C 1998, Legitimacy and the European Union, Routledge, New York.

Bormann, AL; Bülow, JC \& Østrup, C 2002, Loven. Om udarbejdelse af lovforslag, Jurist- og Økonomforbundets Forlag, København.

CEPOS 2009, 'Delegation og bekendtgørelser i Danmark - et retssikkerhedsmæssigt problem?', hentet fra

http://www.cepos.dk/sites/default/files/analyse_publication/Delegation_og_bekendtgoerelse

r_i_Danmark__et_retssikkerhedsmaessigt_problem.pdf [1. juni 2015].

Christensen, JG 1991, Den usynlige stat, Gyldendal, København.

Civilstyrelsen $\quad$ udateret, 'Om retsinformation.dk', hentet fra https://www.retsinformation.dk/Forms/R0500.aspx [13. november 2014].

Danmarks Riges Grundlov 1953.

De Mesquita, EB \& Stephenson, MC 2007, 'Regulatory Quality Under Imperfect Oversight', American Political Science Review, vol. 101, no. 3, pp. 605-620.

Djankov, S; McLiesh, C \& Ramalho, RM 2006, 'Regulation and growth', Economics Letters, vol. 92, no. 3, pp. 395-401.

Erhvervs- og Vækstministeret 2013, 'Besvarelse af spørgsmål 25 til L 153 stillet af Erhvervs-, Vækstog Eksportudvalget den 24. april 2013 efter ønske fra Kim Andersen (V)', Folketinget, hentet fra http://www.ft.dk/samling/20121/lovforslag/1153/spm/25/svar/1049392/1243133.pdf [17. november 2014].

Finansministeriet 2005, Vejledning om konsekvensanalyser, Finansministeriet, København.

Fliedner, O 2001, Gute Gesetzgebung. Welche Möglichkeiten gibt es, bessere Gesetze zu machen?, Friedrich-Ebert-Stiftung, hentet fra http://library.fes.de/pdf-files/stabsabteilung/01147.pdf [19. december 2014].

Folketinget 2013, Forretningsorden for Folketinget, Folketinget, København.

Germer, P 2007, Statsforfatningsret, 4. udg., Jurist- og Økonomforbundets Forlag, København.

Haidar, JI 2012, 'The impact of business regulatory reforms on economic growth', Journal of the Japanese and International Economies, vol. 26, no. 3, pp. 285-307.

Hansen, HF \& Pedersen, LH 2006 'The Dynamics of Regulatory Reform', i T Christensen \& P Lægreid (red.), Autonomy and Regulation: Coping With Agencies in the Modern State, Edward Elgar, Cheltenham, pp. 328-355.

Huynh, KP \& Jacho-Chávez, DT 2009, 'Growth and governance: A nonparametric analysis', Journal of Comparative Economics, vol. 37, no. 1, pp. 121-143.

Jakobsen, MLF \& Mortensen, PB 2014, Regelstaten. Vaksten i danske love og bekendtgørelser 19892011, Jurist- og Økonomforbundets Forlag, København. 
Jalilian, H; Kirkpatrick, C \& Parker, D 2007, 'The Impact of Regulation on Economic Growth in Developing Countries: A Cross-Country Analysis', World Development, vol. 35, no. 1, pp. 87-103.

Justitsministeriet 2005, Vejledning om lovkvalitet, Justitsministeriet, København.

Kaeding, M 2008, 'In search of better quality of EU regulations for prompt transposition: The Brussels perspective', European Law Journal, vol. 14, no. 5, pp. 583-603.

Kelsen, H 1928, Die philosophischen Grundlage der Naturrechtslehre und des Rechtspositivismus, Pan-Verlag Rolf Heise, Berlin.

Majone, G 1994, 'The rise of the regulatory state in Europe', West European Politics, vo. 17, no. 3, pp. 77-101.

Majone, G 1996, Regulating Europe, Routledge, New York.

Majone, G 1998, 'Europe's «Democratic Deficit»: The Question of Standards', European Law Journal, vol. 4, no. 1, pp. 5-28.

Majone, G 1999, 'The regulatory state and its legitimacy problems', West European Politics, vol. 22, no. 1, pp. 1-24.

Matzen, H 1900, Den Danske Statsforfatningsret, 3. udg., JH Schultz Forlag, København.

Müller, G \& Uhlmann, F 2013, Elemente einer Rechtssetzungslehre, Schulthess, Zürich.

Olsen, JP 1978, Politisk organisering : organisasjonsteoretiske synspunkt på folkestyre og politisk ulikhet, Universitetsforlaget, Oslo.

Painter, JM 2009, Legal Writer: 40 Rules for the Art of Legal Writing, 4. udg., Jarndyce \& Jarndyce, Cincinnati, $\mathrm{OH}$.

Pedersen, MJ 2015 'Neglecting Results? A Critical View of the Literature on Organised Interest in the European Union', Journal of Public Affairs, http://doi.org/DOI: 10.1002/pa.1588

Pedersen, MJ \& Pasquali, S 2009, 'Regelforenkling og administrative lettelser - med panden mod muren?', Tidsskriftet Politik, vol. 12, no. 3, pp. 65-75.

Pedersen, MJ; Ravn, J \& Christensen, GL 2014, 'Øget brug af samlelove besværliggør kvalitetskontrol', Dansk Erhvervs Perspektiv, vol. 19/2014.

Radaelli, CM 2004, 'Getting to Grips with Quality in the Diffusion of Regulatory Impact Assessment in Europe', Public Money and Management, vol. 24, no. 5, pp. 271-276.

Radaelli, CM 2005, 'Diffusion without convergence: how political context shapes the adoption of regulatory impact assessment', Journal of European Public Policy, vol. 12, no. 5, pp. 924 943.

Radaelli, CM \& de Francesco, F 2007, Regulatory Quality in Europe: Concepts, Measures and Policy Processes, Manchester University Press, Manchester.

Radaelli, CM \& Meuwese, ACM 2009, 'Better Regulation in Europe: Between Public Management and Regulatory Reform', Public Administration, vol. 87, no. 3, pp. 639-654.

Rodrik, D 2005, 'Growth Strategies', i P Aghion \& S Durlauf (red.), Handbook of Economic Growth, Elsevier, Amsterdam, Bind A, pp. 967-1014.

Scharpf, F 2009, 'Legitimacy in the Multilevel European Polity', European Political Science Review, vol. 1, no. 2, pp. 173-204. 
Statsministeriet 1998, Cirkulaere nr. 159 af 16. september 1998 om bemcerkninger til lovforslag og andre regeringsforslag og om fremgangsmåden ved udarbejdelse af lovforslag, redegørelser, administrative forskrifter m.v..

Stern, J \& Cubbin, J 2005, 'Regulatory Effectiveness: The Impact of Regulation and Regulatory Governance Arrangements on Electricity Industry Outcomes', World Bank Policy Research Working Paper, vol. 3536.

Stern, J \& Holder, S 1999, 'Regulatory governance: criteria for assessing the performance of regulatory systems: an application to infrastructure industries in the developing countries of Asia', Utilities Policy, vol. 8, no. 1, pp. 33-50.

Sørensen, JS 1999, '§ 3', i H Zahle (red.), Danmarks Riges Grundlov med kommentarer, Jurist- og Økonomforbundets Forlag, København, pp. 37-45.

Van Hoecke, M \& Warrington, M 1998, 'Legal cultures, legal paradigms and legal doctrine: towards a new model for comparative law', International and Comparative Law Quarterly, vol. 47, no. 3, pp. 495-536.

Wegener, M 2000, Juridisk metode, 3. udg., Jurist- og Økonomforbundets Forlag, København.

Wiener, JB 2006, 'Better Regulation in Europe', Duke Law School Faculty Scholarship Series, vol. 65 , hentet fra http://www.ecipe.org/media/publication_pdfs/Better_Regulation_in_Europe.pdf $[17$. september 2014]. 